\title{
Life history of three catfish species (Siluriformes: Ariidae) from southeastern Brazil
}

\author{
Márcia Regina Denadai , Eduardo Bessa ${ }^{2}$, Flávia Borges Santos ${ }^{3}$, Wellington Silva Fernandez $z^{4,6}$, \\ Fernanda Motta da Costa Santos ${ }^{5}$, Mônica Malagutti Feijó ${ }^{5}$, \\ Andreza Cristina Dias Arcuri ${ }^{5}$ \& Alexander Turra ${ }^{4}$ \\ ${ }^{1}$ Centro Universitário Módulo, Av. Frei Pacifico Wagner, 653, CEP 11660-903, Caraguatatuba, SP, Brasil \\ ${ }^{2}$ Laboratório de Ecologia Comportamental da Reprodução, Universidade do Estado de Mato Grosso - \\ UNEMAT, Rod. MT-358, Km 7, Jardim Aeroporto, CEP 78300-000, Tangara da Serra, MT, Brasil \\ ${ }^{3}$ Departamento de Ciências Naturais, Universidade Estadual do Sudoeste da Bahia - UESB, \\ Estrada do Bem Querer, Km 4, CEP 45083-900, Vitória da Conquista, BA, Brasil \\ ${ }^{4}$ Centro Universitário da Fundação de Ensino Octávio Bastos, Av. Dr. Octávio Bastos, $s / n$, \\ Jardim Nova São João, CEP 13870-000, São João da Boa Vista, SP, Brasil \\ ${ }^{5}$ Departamento de Oceanografia Biológica, Instituto Oceanográfico, Universidade de São Paulo - USP, \\ Praça do Oceanográfico, 191, Cidade Universitária, CEP 05508-120, São Paulo, SP, Brasil \\ ${ }^{6}$ Corresponding author: Wellington Silva Fernandez, e-mail: fernandez@usp.br
}

DENADAI, M.R., BESSA, E., SANTOS F.B., FERNANDEZ, W.S., SANTOS, F.M.C., FEIJÓ, M.M., ARCURI, A.C.D. \& TURRA, A. Life history of three catfish species (Siluriformes: Ariidae) from southeastern Brazil. Biota Neotrop. 12(4): http://www.biotaneotropica.org.br/v12n4/en/abstract?article+bn01912042012

\begin{abstract}
This study evaluated the spatio-temporal distribution, reproduction and diet of the catfishes Genidens genidens, G. barbus and Aspistor luniscutis in Caraguatatuba Bay. Their sizes were recorded and the sex and reproductive stage identified. The abundance was compared between areas (South and North) and among months (August 2003 - October 2004). The species had different spatial distributions, allowing them to coexist. The temporal distribution reflected their tendencies to migrate in the reproductive period, as evidenced by the dominance of small immature individuals in the bay. G. genidens tended to reproduce in winter, and A. luniscutis in spring. The diet of $G$. genidens consisted of crustaceans, mollusks (shells), fish scales, ostracods, and bivalve siphons. G. barbus consumed a high proportion of mysids, followed by fish (bones and scales). For A. luniscutis, the diet was based on fish scales and crustaceans. High quantities of particulate organic matter were observed in the diet of all three species, as previously known for estuarine catfishes. The consumption of fish scales may reflect a lepidophagic habit. A small overlap was observed among the diets, reflecting differences in their environments as well as in the proportions of each item ingested.
\end{abstract}

Keywords: spatio-temporal distribution, diet, Genidens genidens, Genidens barbus, Aspistor luniscutis, Caraguatatuba Bay.

DENADAI, M.R., BESSA, E., SANTOS F.B., FERNANDEZ, W.S., SANTOS, F.M.C., FEIJÓ, M.M., ARCURI, A.C.D. \& TURRA, A. Ciclo de vida de três espécies de bagres (Siluriformes: Ariidae) do sudeste do Brasil. Biota Neotrop. 12(4): http://www.biotaneotropica.org.br/v12n4/pt/abstract?article+bn01912042012

Resumo: Este estudo teve como objetivo avaliar a distribuição espaço-temporal, reprodução e dieta dos bagres Genidens genidens, G. barbus e Aspistor luniscutis na Enseada de Caraguatatuba. Seus tamanhos foram registrados e o sexo e o estágio reprodutivo identificados. A abundância foi comparada entre areas (sul e norte) e entre meses (agosto/2003 a outubro/2004). As espécies tiveram distribuições espaciais distintas, permitindo sua coexistência. A distribuição temporal reflete sua tendência por migrar no períoo reprodutivo, evidenciado pela dominância de indivíduos pequenos e imaturos na enseada. Houve uma tendência de G. genidens reproduzir no inverno e A. luniscutis na primavera. G. genidens teve sua dieta constituida de crustáceos, moluscos (conchas), escamas de peixes, ostrácodes e sifões de bivalves. G. barbus revelou uma grande dominância por misidáceos, seguido por peixes (ossos e escamas). Para A. luniscutis, a dieta foi baseada em escamas de peixes e crustáceos. Grande quantidade de material orgânico particulado foi observado na dieta das espécies, como já conhecido para bagres estuarinos. O consumo de escamas de peixes pode refletir um hábito lepdofágico. Pequena sobreposição na dieta foi observada entre as espécies, refletindo distinções no ambiente como também nas proporções ingeridas de cada item.

Palavras-chave: distribuição espaço-temporal, dieta, Genidens genidens, Genidens barbus, Aspistor luniscutis, Enseada de Caraguatatuba. 


\section{Introduction}

The family Ariidae includes the catfishes, marine and brackish water leather fishes (Figueiredo \& Menezes 1978). The family has a wide distribution in tropical and temperate waters, and its members occur near the coast, in estuaries and inland waters; few are strictly marine (Marceniuk \& Menezes 2007). The catfishes seek out river mouths and lagoons during the spawning period (Figueiredo \& Menezes 1978). They have a wide feeding spectrum, which may vary during their ontogenetic development, with the diet mostly constituted of detritus, decapods, fish, polychaetes and bivalves (Espírito Santo \& Isaac 1999). The reproduction occurs normally, in the warmer months of the year or during the rainy period, when there is a major uptake from rivers (Mazzoni et al. 2000, Gomes \& Araújo 2004, Fávaro et al. 2005).

Genidens genidens occurs in South America, from Brazil to Argentina (Marceniuk \& Menezes 2007). It is one of the most common catfishes of the Brazilian coast and is found in large numbers in estuaries and lagoons (Figueiredo \& Menezes 1978). It may reach $35 \mathrm{~cm}$ in total length (Figueiredo \& Menezes 1978, Marceniuk \& Menezes 2007). Of the three species studied here, G. genidens is the most studied with respect to several aspects, including distribution (Mishima \& Tanji 1981, Azevedo et al. 1999), diet (Mishima \& Tanji 1982, Araújo 1984, Chaves \& Vendel 1996, Rabitto \& Abilhôa 1999), reproduction (Barbieri et al. 1992, Gomes et al. 1999, Mazzoni et al. 2000) and fisheries (Reis 1986).

Genidens barbus occurs over the same range as G. genidens, in Brazil, Uruguay and Argentina (Marceniuk \& Menezes 2007). It is predominantly marine, but may occur also in brackish waters (Marceniuk \& Menezes 2007), where it migrates in the period prior to spawning (Figueiredo \& Menezes 1978). It is one of the largest (up to $1 \mathrm{~m}$ in total length) and most common catfishes of the Brazilian coast and feeds on molluscs, crustaceans and other benthic invertebrates (Figueiredo \& Menezes 1978). Very little is known about its biology apart from a few records of its diet (Mishima \& Tanji 1982, Araújo
1984), age, growth, reproduction (Reis 1986) and distribution (Azevedo et al. 1999).

Aspistor luniscutis occurs along the eastern coast of South America from the Guianas to Brazil, and may reach a maximum length of $1.2 \mathrm{~m}$ (Figueiredo \& Menezes 1978). Like the other species, it occupies marine and brackish environments (Marceniuk \& Menezes 2007). Knowledge about this species is also very sparse (Mishima \& Tanji 1982, Azevedo et al. 1999).

Caraguatatuba Bay is a sheltered area influenced by a small estuary on the Brazilian southeast coast, and little information on its ichthyofauna is available. This bay receives constant continental freshwater input, making it an appropriate environment for catfishes (Figueiredo \& Menezes 1978). Besides the three species mentioned here, the madamango sea catfish Cathorops spixii is the most numerous species recorded for the area (Santos et al., unpublished data). In view of the great diversity of fishes in the region (Santos et al., unpublished data) and the significant human impacts on this bay, the present study is the result of a pioneer effort to evaluate the fish fauna of this environment, generating a basis for its management in terms of biodiversity and fisheries.

The present study describes the spatio-temporal distribution, size-class distribution, reproductive aspects, and diets of the catfishes Genidens genidens, Genidens barbus and Aspistor luniscutis from Caraguatatuba Bay.

\section{Materials and Methods}

\section{Study area}

Caraguatatuba Bay $\left(23^{\circ} 37^{\prime} \mathrm{S}\right.$ to $23^{\circ} 44^{\prime} \mathrm{S}$ and $45^{\circ} 24^{\prime} \mathrm{W}$ to $45^{\circ} 26^{\prime} \mathrm{W}$ ) has a total shoreline of about $16 \mathrm{~km}$, with several sandy beaches (Enseada, Flecheiras, Porto Novo, Romance, Palmeiras, Pan-Brasil, Indaiá, Centro and Camaroeiros; Figure 1).

Two areas with $2 \times 2 \mathrm{~km}$ each, homogeneous but differing from each other, were selected for this study (Figure 1). These areas

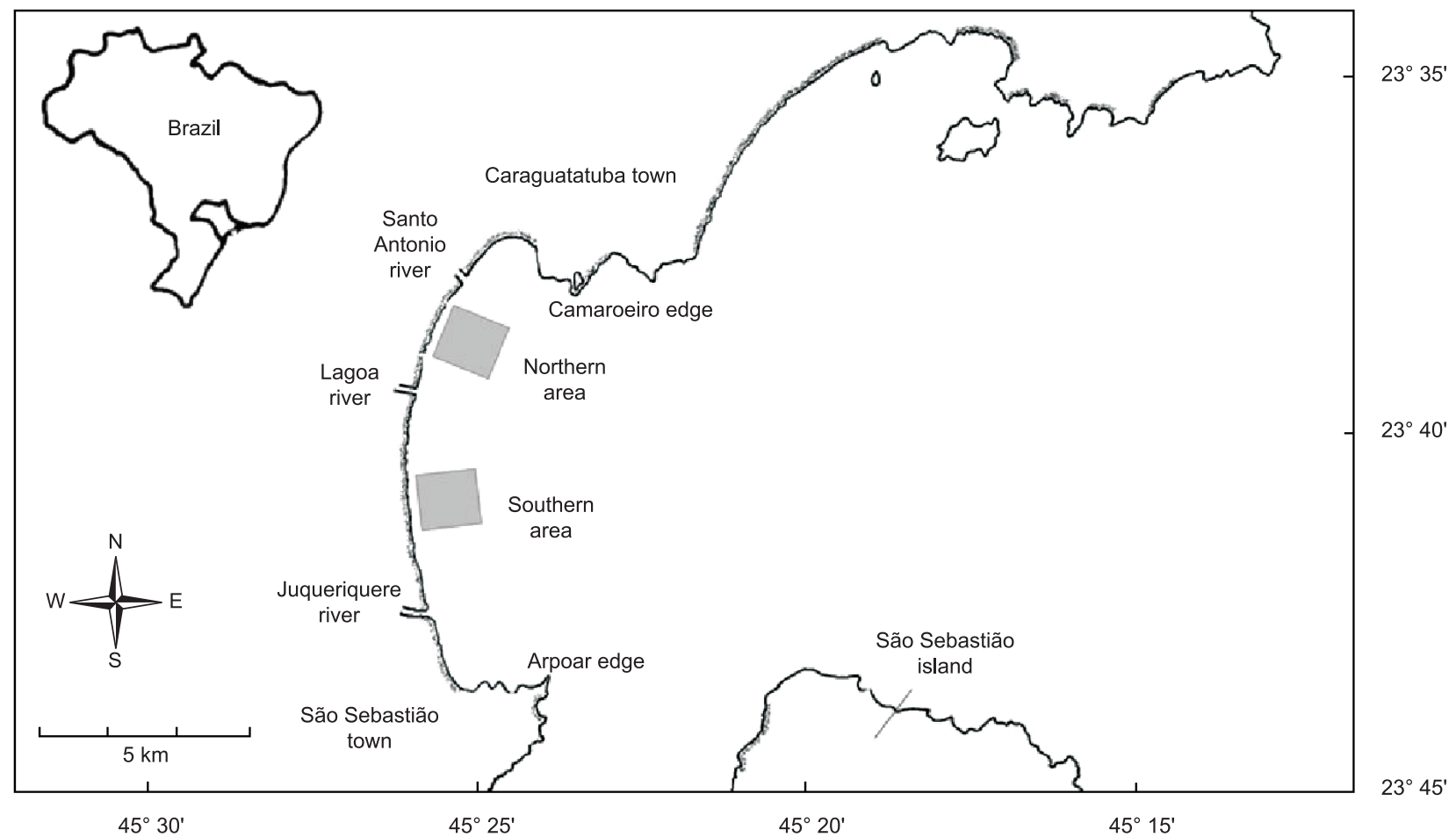

Figure 1. Caraguatatuba Bay. The study areas (South and North) are indicated by gray squares. 
were located so as to exclude the strong influence of the local rivers (Juqueriquerê, Lagoa and Santo Antônio). The first (South) area extends from Porto Novo to Palmeiras beaches, and has a gentler slope. It is more exposed to wave activity and is influenced by the presence of the Juqueriquerê River, with the constitution of a small estuary. The North area, extending from Indaiá to Centro beaches, has a steeper slope. It is relatively sheltered from wave energy and is slightly influenced by the smaller rivers (Lagoa and Santo Antônio).

\section{Sampling methods}

Monthly samples were taken between August 2003 and October 2004. Three sampling stations were selected in each area, South and North, among 200 possibilities, i.e., the beach length of $2000 \mathrm{~m}$ divided into 10-m intervals. The position of each station was stored in a GPS at MLW (mean low water) and then the distance of $800 \mathrm{~m}$ was located, in a perpendicular way, using a fishing boat (class G2M, $11 \mathrm{~m}$ long, with a 22-HP engine).

At each station an $800-\mathrm{m}$ trawl was performed, from 800 to $1600 \mathrm{~m}$ from MLW. This interval is equivalent to a depth from 1 to $4 \mathrm{~m}$. The trawling speed was $1 \mathrm{knot}$. The trawls were performed using two otter trawls with a $2.0 \mathrm{~cm}$ mesh, mouth aperture of $1.6 \mathrm{~m}$ in height and $6.0 \mathrm{~m}$ in length, bag depth of $3.5 \mathrm{~m}$.

The fish were then removed from the net and immediately preserved in a $10 \%$ formalin solution in order to paralyze the enzyme action, preserving the gut contents (Uieda \& Castro, 1999). The samples were identified and stored in plastic containers. After identification of species in the laboratory, all specimens were transferred to $70 \%$ ethanol.

\section{Population analysis and diet}

All individuals of G. genidens, G. barbus, and A. luniscutis obtained in the samples were measured for standard length (SL), which is the distance between the anterior head edge and the edge of the caudal fin base (Figueiredo \& Menezes 1978). No population analysis was performed for G. barbus, which had only 20 individuals sampled. Genidens genidens had 204 individuals and A. luniscutis, 357.

A total of 160 individuals of $G$. genidens and A. luniscutis were selected, using a random-digits table, for the diet analysis, while for $G$. barbus all 20 individuals obtained were used. A ventro-sagittal incision was made in the abdomen, from the anal aperture to the pelvic-fin insertions. The gut and gonads were removed. The gonads were analyzed for sex and classified according to the maturation staged suggested by Vazzoler (1996).

The digestive tube length (distance from the beginning of the esophagus to the end of the rectum; DTL) was measured in order to establish the DTL/SL ratio (digestive-tube length/standard length) and to examine a possible relationship to the diet of each species (Knöppel 1970). The digestive tubes were then preserved in $70 \%$ ethanol until the diet contents analysis.

The digestive tubes were divided into two portions, the first constituted by pharynx, esophagus and stomach, and the second by the intestine and rectum, due to the different digestive degree found in each portion. Finally, the contents of each digestive tube were identified to the lowest possible taxonomic level. The volume of each item was measured according to methodologies from Bemvenute (1990), in which each food item is compressed between two plastic slides $(30 \times 30 \times 1 \mathrm{~mm})$ and the area $\left(\mathrm{mm}^{3}\right)$ measured using graph paper.

\section{Data analysis}

The mean number of individuals ( $+\mathrm{SE})$ of G. genidens and A. luniscutis was calculated for the study months and areas (South and
North). The sum of the areas was also calculated. Two-way ANOVA was performed to evaluate differences in the spatial (areas) and temporal (months) distribution. Histograms illustrating the relative frequency distribution of the size classes (standard length) of these two species were plotted for the total population. A chi-square test was performed to verify if the sex ratio was equal between males and females, with $\alpha=0.05$.

The diets of G. genidens, G. barbus, and A. luniscutis were analyzed by the frequency of occurrence (F\%), percent volume (V\%), and index of alimentary importance (IAi). The F\% is the frequency of digestive tubes containing a given food item in relation to the total number of digestive tubes containing any food item; $\mathrm{V} \%$ is the volume of a given food item in relation to the volume of the total food items in the diet. The index of alimentary importance (IAi) was calculated by the method used by Kawakami \& Vazzoler (1980), based on the frequency of occurrence and on the percent volume of each item. Seasonal analysis was possible only for A. luniscutis, because the individuals of this species were uniformly distributed in the study period. A similarity index (Krebs, 1989) was calculated to assess the overlap of the diets of the three ariid species.

\section{Results}

The three species were not numerous in the bay. In the 15 months, 204 individuals of G. genidens, only $20 \mathrm{G}$. barbus, and 357 A. luniscutis. Genidens genidens occurred during the entire year (Figure 2), and was more abundant in the summer (January to April/2004) $(\mathrm{F}=6,774 ; \mathrm{df}=13 ; \mathrm{p}<0.001)$, with no significant difference between the North and South areas $(\mathrm{F}=0,726$; $\mathrm{df}=1$; $\mathrm{p}=0.398$ ). The spatio-temporal distribution (areas $\times$ months) did not evidence any interactions between the two variables $(\mathrm{F}=1,562$; $\mathrm{df}=13 ; \mathrm{p}=0.125$ ). For $G$. barbus, the few individuals obtained showed a tendency to occur preferentially in summer (January to April/2004) and in the South area, although these results were not confirmed by Anova (Months: $\mathrm{F}=0,880 ; \mathrm{df}=13 ; \mathrm{p}=0.578$; Areas: $\mathrm{F}=1,984 ; \mathrm{df}=1 ; \mathrm{p}=0.164 ;$ Months*Areas: $\mathrm{F}=0,933 ; \mathrm{df}=13$; $\mathrm{p}=0.527)$. Aspistor luniscutis was also present during the entire sampling period, although with a tendency toward higher densities during the autumn (March to June/2004) ( $\mathrm{F}=2,490$; df $=13$; $\mathrm{p}=0.009)$, and occurred almost exclusively in the South area $(\mathrm{F}=18,066 ; \mathrm{df}=1 ; \mathrm{p}<0.001)$. The spatio-temporal distribution (areas $\times$ months) indicated a significant interaction between these two variables $(\mathrm{F}=2,393 ; \mathrm{df}=13 ; \mathrm{p}=0.012)$.

With respect to the size distribution (Figure 3), G. genidens showed standard lengths between 8.3 and $25.7 \mathrm{~cm}$, with a mean SL of $13.00 \pm 3.51 \mathrm{~cm}$. Lengths of G. barbus ranged from 6.9 to $14.6 \mathrm{~cm}$, with a mean of $11.94 \pm 1.82 \mathrm{~cm}$. Aspistor luniscutis showed the widest size range, from 4.7 to $30.5 \mathrm{~cm}$, with a mean of $12.12 \pm 5.75$.

Many individuals of all three catfishes were immature and therefore did not have their sexes identified (Figure 4). The sex ratio of $G$. genidens was 1:1.93 (female: male) in the four seasons $\left(\chi^{2}=450 ; \mathrm{df}=1 ; \mathrm{p}<0.001\right)$. The number of maturing individuals tended to increase from spring to winter, when most were sexually mature. In G. barbus, $68 \%$ of individuals were sexually immature. Considering the adults, males dominated over females during autumn; three males were obtained in the spring and five females in the summer; no individual of this species was collected in the winter. The proportion of G. barbus with maturing gonads in relation to immatures, increased gradually from the autumn to the summer. For A. luniscutis, sexually immature individuals comprised $68 \%$ of the total; among adults, females predominated in the autumn and spring, males in the summer, and the sexes were in equal proportions in winter $\left(\chi^{2}=144,5 ; \mathrm{df}=1 ; \mathrm{p}<0.001\right)$. The proportion of mature 

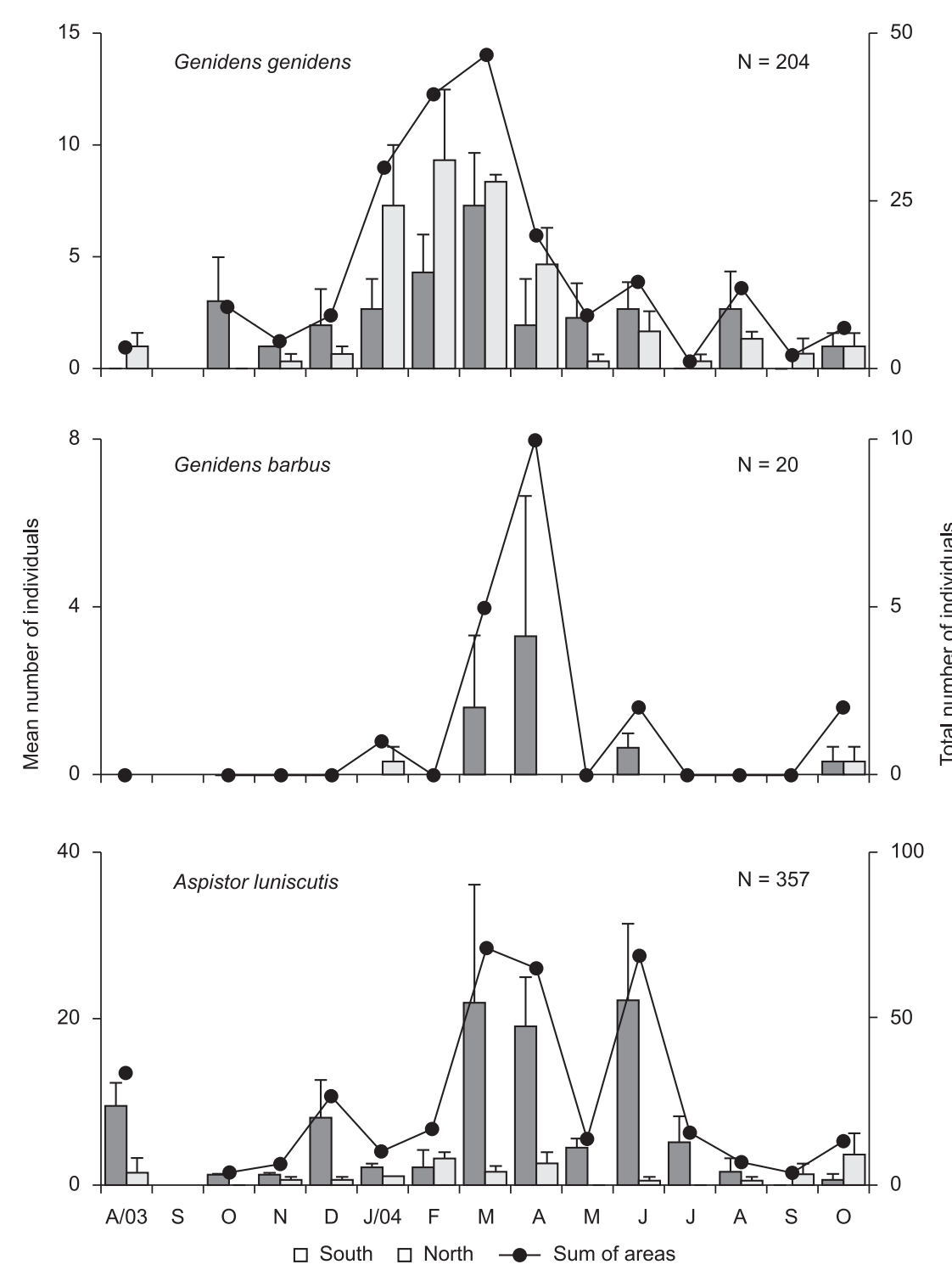

Figure 2. Genidens genidens, Genidens barbus, and Aspistor luniscutis. Monthly mean (+standard error) number of individuals/trawl in each of the two study areas (South and North) and monthly total number of individuals in the two areas.

individuals tended to increase from autumn to spring. In the summer, there were proportionally more maturing individuals, although with a small percentage of individuals with empty gonads, suggesting that spawning occurs in summer.

In relation to the diet (Table 1), G. genidens consumed 15 items, including plants (algae, seeds), benthic and planktonic invertebrates, vertebrates, and eggs; G. barbus consumed six different items, basically crustaceans, echinoderms, and fish; and A. luniscutis contained 12 items in its diet, constituted by algae, benthic and planktonic invertebrates, and fish. The calculated DTL/SL ratios were $1.23,1.43$ and 1.15 respectively, for G. genidens, G. barbus and A. luniscutis.

Comparing the frequency of occurrence of the items ingested in the different portions of the digestive tube, stomach, and intestine, the largest variety of items was observed in the stomach for all three species (Table 1), although with some differences. For G. genidens, the items most frequently found in the stomach were unidentified crustacean fragments and fish scales, while in the intestine, fragments of bivalve shells were more frequent. For G. barbus, the intestine contained unidentified crustacean fragments and amphipod tubes, but no mysids. For A. luniscutis, although the most frequent item in both portions was fish scales, unidentified crustacean fragments were relatively frequent in the stomach but absent in the intestine. Shell fragments were very frequent in the intestine and less frequent in the stomach.

In terms of volume (Table 1), bivalve shells and crustaceans were the most important items in both the stomach and intestine of G. genidens, although other items also were relatively important in the stomach. In G. barbus, mysids were the most voluminous item in the stomach, while fish scales dominated the intestine volume. For A. luniscutis, the most voluminous items in the stomach were crustaceans and fish scales; in the intestine, shell fragments were the most voluminous. A wider variety of voluminous items was observed in the stomachs of these species.

For G. genidens, the most important item in the stomach contents was unidentified crustaceans (fragments) (Figure 5), followed by bivalves (shells), fish (scales), ostracods, and bivalve siphons. Ten other items showed relatively important frequencies or volumes, although the calculated relative importance was lower than $5 \%$. The mysids were the absolute item in importance for G. barbus, occurring 


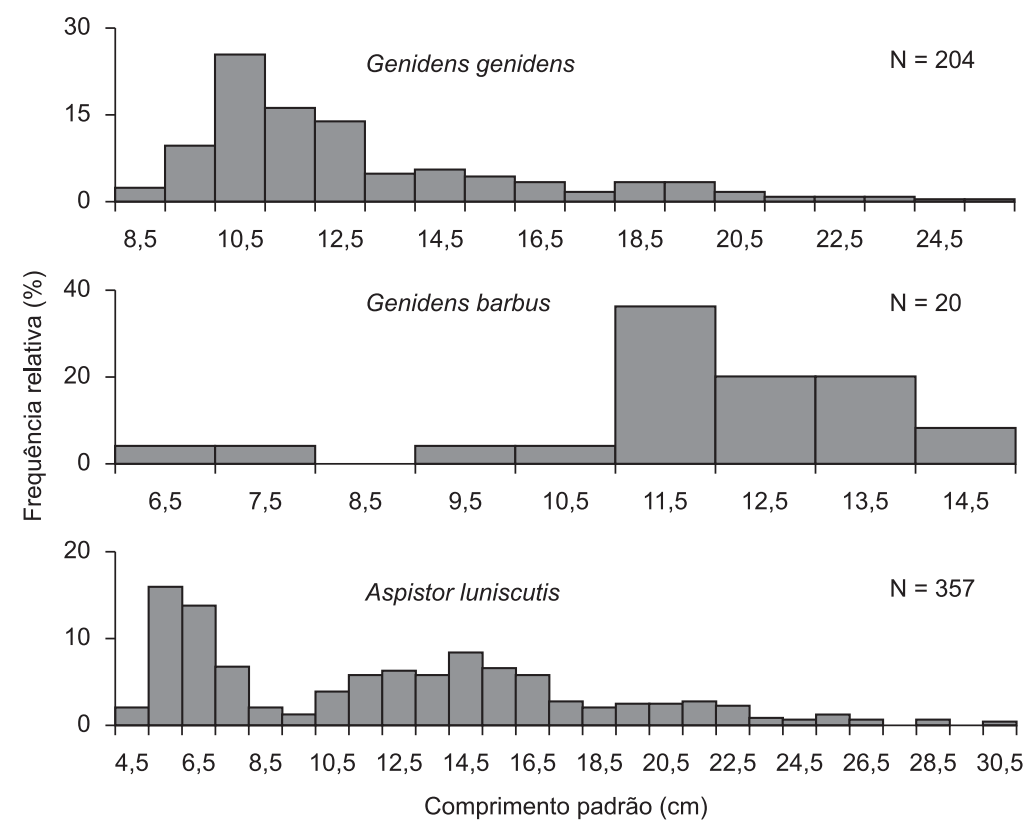

Figure 3. Genidens genidens, Genidens barbus, and Aspistor luniscutis. Size (standard length - $\mathrm{cm}$ ) frequency distribution of individuals in the study period.

in half of the stomachs and comprising $92 \%$ of the total volume of this catfish's diet. Fish (bones and scales) also showed a certain importance in the diet of G. barbus. In A. luniscutis, fish (scales), followed by crustaceans (fragments) dominated the diet. Bivalves (siphons and shells) and polychaetes were also relatively important in this species' diet.

The only species for which a seasonal analysis of the diet was possible was $A$. luniscutis. In relation to the frequency of occurrence, fish scales were the most frequent item during the entire study period (Figure 6). The second most frequent item was crustacean fragments. In autumn, bivalve siphons also appeared. During winter, polychaetes and mysids were relatively important in frequency. Polychaetes also appeared in spring, when the diversity of items in the diet was highest. In relation to volume (Figure 7), fish scales were the most voluminous item in autumn and summer, while crustaceans (fragments) were prominent in winter and spring. Mysids were also relatively important during winter.

The similarity indexes calculated for the sympatric catfishes in Caraguatatuba Bay revealed, in general, no overlap in the diet of the three species $(\mathrm{Gg} \times \mathrm{Gb}=1.61 \%$; $\mathrm{Gg} \times \mathrm{Al}=37.64 \%$; $\mathrm{Gb} \times \mathrm{Al}=2.37 \%)$. Only $G$. genidens and A. luniscutis showed a small overlap in the items crustaceans (fragments) and fish scales.

\section{Discussion}

The three catfish species had distinct spatial distributions in Caraguatatuba Bay. Genidens genidens occurred in both study areas (South and North), with a slightly higher abundance in the North area. Genidens barbus and Aspistor luniscutis showed highr densities in the South area, which is more frequently influenced by freshwater input. Ribeiro Neto (1993) observed in the Santos and São Vicente bay-estuary complex, that of the three species studied here, G. barbus seemed to be more abundant off the beaches, and G. genidens and A. luniscutis in more-structured environments (biogenic bottoms and parcels). Schmidt et al. (2008) observed a possible preference of the three species for more-protected estuarine environments. Azevedo et al. (1999) suggested that spatial-separation strategies could explain the coexistence of marine catfishes in Sepetiba Bay. G. genidens was abundant at all stations in the inner bay, G. barbus was abundant near the river mouth, while $A$. luniscutis was widely distributed in the inner and outer bay. In relation to environmental parameters, Mishima \& Tanji (1981) observed in the Cananéia estuary, that $G$. genidens and A. luniscutis occurred in a wide salinity range (0.1 to 33), while juvenile G. barbus concentrated in higher salinities (15 to 33), and suggested that adults of this last species live in the open sea. Thus, the differences in spatial distribution among the three species found here may result from a tendency for G. genidens to occur over a wide salinity range, i.e., from the South to the North area. On the other hand, the low numbers of G. barbus in Caraguatatuba Bay may be a function of its plasticity in also occupying the open sea, reflecting a possible spatial segregation between the two species as a means of coexistence.

In relation to the temporal distribution, G. genidens and G. barbus were more abundant in the bay during the summer months, while A. luniscutis was observed in larger numbers in autumn. Many species of marine catfishes make seasonal movements in different phases of their life cycles, when they seek out river mouths and lagoons in the spawning period (Figueiredo \& Menezes 1978, Mishima \& Tanji 1981, Reis 1986, Azevedo et al. 1999). Bento \& Bemvenuti (2008) observed a predominance of $G$. genidens in the northern portion of the Lagoa dos Patos estuary, mainly from May to December. According to Mishima \& Tanji (1982), G. genidens and A. luniscutis always live in brackish water, while G. barbus is a migratory species that leaves the estuary when it reaches about $20 \mathrm{~mm}$ and returns to it as an adult for spawning. Schmidt et al. (2008), on the other hand, found that $G$. genidens and $A$. luniscutis were constant in the inner region of the São Vicente estuary, where they occur in the juvenile pre-maturation phase, and do not reproduce there.

The mean standard lengths obtained for the three species (G. genidens: mean $=13.0 \mathrm{~cm}$ and $\max .=25.7 \mathrm{~cm} ;$ G. barbus: mean $=11.9 \mathrm{~cm}$ and $\max .=14.6 \mathrm{~cm} ;$ A. luniscutis: mean $=12.1 \mathrm{~cm}$ and max. $=30.5 \mathrm{~cm}$ ) indicate that the study area is dominated by juvenile individuals, because the largest known individuals of the three species measured, respectively, $35 \mathrm{~cm}, 1.0 \mathrm{~m}$ and $1.2 \mathrm{~m}$ (Figueiredo \& Menezes 1978). Most individuals measured in this study (G. genidens: 42\%; G. barbus: 68\%; A. luniscutis: $68 \%$ ) had not yet reached sexual maturity. For G. genidens, some lengths at 
Table 1. Genidens genidens, Genidens barbus, and Aspistor luniscutis. Frequency of occurrence (F\%), percent volume (V\%) and index of alimentary importance $\left(\mathrm{IA}_{\mathrm{i}}\right)$ in the stomach and intestine portions.

\begin{tabular}{|c|c|c|c|c|c|c|}
\hline & \multicolumn{6}{|c|}{ Genidens genidens } \\
\hline & \multicolumn{3}{|c|}{ Stomach } & \multicolumn{3}{|c|}{ Intestine } \\
\hline & $\mathbf{F \%}$ & $\mathrm{V} \%$ & $\mathbf{A \mathbf { I } _ { i }}$ & $\mathbf{F \%}$ & $\mathrm{V} \%$ & $\mathbf{A \mathbf { I } _ { i }}$ \\
\hline Algae & 6.90 & 3.44 & 1.63 & 22.22 & 3.48 & 2.64 \\
\hline Seed & 1.72 & 8.83 & 1.04 & 0.00 & 0.00 & 0.00 \\
\hline Nemertine & 6.90 & 1.81 & 0.86 & 0.00 & 0.00 & 0.00 \\
\hline Polychaeta & 13.79 & 4.77 & 4.51 & 0.00 & 0.00 & 0.00 \\
\hline Bivalve shells & 8.62 & 23.49 & 13.88 & 44.44 & 37.39 & 56.67 \\
\hline Bivalve siphon & 15.52 & 7.55 & 8.03 & 0.00 & 0.00 & 0.00 \\
\hline Crustacean fragments & 24.14 & 28.45 & 47.08 & 22.22 & 48.26 & 36.57 \\
\hline Amphipod & 10.34 & 2.34 & 1.66 & 11.11 & 2.17 & 0.82 \\
\hline Copepoda & 5.17 & 0.18 & 0.06 & 0.00 & 0.00 & 0.00 \\
\hline Ostracoda & 15.52 & 7.95 & 8.46 & 11.11 & 7.39 & 2.80 \\
\hline Shrimp & 10.34 & 1.63 & 1.16 & 0.00 & 0.00 & 0.00 \\
\hline Briozoa & 1.72 & 0.18 & 0.02 & 0.00 & 0.00 & 0.00 \\
\hline Fish scales & 20.69 & 7.90 & 11.21 & 11.11 & 0.87 & 0.33 \\
\hline Fish bone & 3.45 & 1.19 & 0.28 & 0.00 & 0.00 & 0.00 \\
\hline \multirow[t]{4}{*}{ Eggs } & 5.17 & 0.31 & 0.11 & 11.11 & 0.43 & 0.16 \\
\hline & \multicolumn{6}{|c|}{ Genidens barbus } \\
\hline & \multicolumn{3}{|c|}{ Stomach } & \multicolumn{3}{|c|}{ Intestine } \\
\hline & F\% & $\mathbf{V} \%$ & $\mathrm{AI}_{\mathrm{i}}$ & $\mathbf{F} \%$ & $\mathbf{V} \%$ & $\mathrm{AI}_{\mathrm{i}}$ \\
\hline Crustacea & 0.00 & 0.00 & 0.00 & 50.00 & 7.14 & 7.14 \\
\hline Mysidaceae & 50.00 & 81.93 & 93.22 & 0.00 & 0.00 & 0.00 \\
\hline Amphipoda tube & 0.00 & 0.00 & 0.00 & 50.00 & 21.43 & 21.43 \\
\hline Echinodermata & 5.56 & 4.11 & 0.52 & 0.00 & 0.00 & 0.00 \\
\hline Fish scale & 61.11 & 0.96 & 1.33 & 50.00 & 71.43 & 71.43 \\
\hline \multirow[t]{4}{*}{ Fish bone } & 16.67 & 13.00 & 4.93 & 0.00 & 0.00 & 0.00 \\
\hline & \multicolumn{6}{|c|}{ Aspistor luniscutis } \\
\hline & \multicolumn{3}{|c|}{ Stomach } & \multicolumn{3}{|c|}{ Intestine } \\
\hline & $\mathbf{F \%}$ & $\mathbf{V} \%$ & $\mathrm{AI}_{\mathrm{i}}$ & $\mathbf{F} \%$ & $\mathbf{V} \%$ & $\mathrm{AI}_{\mathrm{i}}$ \\
\hline Algae & 1.05 & 1.17 & 0.03 & 0.00 & 0.00 & 0.00 \\
\hline Hidrozoa & 1.05 & 0.53 & 0.02 & 0.00 & 0.00 & 0.00 \\
\hline Polychaeta & 18.95 & 3.92 & 2.09 & 16.67 & 6.11 & 2.59 \\
\hline Shell fragm. & 8.42 & 5.37 & 1.27 & 44.44 & 64.15 & 72.50 \\
\hline Bivalve siphon & 11.58 & 6.96 & 2.26 & 5.56 & 3.38 & 0.48 \\
\hline Crustacean fragm. & 31.58 & 23.21 & 20.59 & 0.00 & 0.00 & 0.00 \\
\hline Mysidacea & 5.26 & 5.79 & 0.86 & 0.00 & 0.00 & 0.00 \\
\hline Amphipoda & 1.05 & 0.09 & 0.00 & 0.00 & 0.00 & 0.00 \\
\hline Isopoda & 1.05 & 0.42 & 0.01 & 0.00 & 0.00 & 0.00 \\
\hline Crab & 6.32 & 3.53 & 0.63 & 0.00 & 0.00 & 0.00 \\
\hline Fish scales & 55.79 & 45.97 & 72.06 & 38.89 & 24.44 & 24.17 \\
\hline Fish fragm. & 2.11 & 3.03 & 0.18 & 5.56 & 1.93 & 0.27 \\
\hline
\end{tabular}

Total number of individuals ( $\mathrm{N}=160,20,160$, respectively), individuals with empty digestive tube $(\mathrm{Ne}=1,0,1)$, mean standard length ( $\mathrm{SL}=12.33$; $11.96 ; 13.62)$, digestive-tube length and standard length ratio (DTL/SL $=1.23 ; 1.43 ; 1.15)$.

first maturation found in the literature were $18.0 \mathrm{~cm}$ for females in Jacarepaguá Lagoon, Rio de Janeiro (Barbieri et al. 1992); 13.3 and $16.0 \mathrm{~cm}$ for females and males, respectively, in Maricá Lagoon, Rio de Janeiro (Mazzoni et al. 2000); for Aspistor luniscutis, in the Rio Sergipe estuary, the estimated value of L50 for both sexes was $17.0 \mathrm{~cm}$ (Alcântara 1989) and for G. barbus the first gonadal maturation for both sexes was estimated at $43.0 \mathrm{~cm}$ in Lagoa dos Patos (Reis 1986).

In Caraguatatuba Bay, G. genidens showed a higher proportion, although in low numbers, of mature individuals in winter than in the other periods, suggesting that spawning occurs in this season. In G. barbus, the number of maturing individuals was higher and the number of immatures lower in summer, although the total number of individuals (20) was too low to infer anything about its reproductive period. For A. luniscutis, a small increase in the number of mature individuals was noted in spring, followed by a small number of spent females in summer, indicating that this species spawns in the spring. Barbieri et al. (1992) observed that, for G. genidens in Lagoa de Jacarepaguá, the spawning period coincided with the highest surfacewater temperatures and lowest salinities (December to January). Mazzoni et al. (2000), also for G. genidens, in Lagoa de Maricá (RJ) determined that the species has total spawning and reproduces between December and April, i.e., austral summer. Gomes et al. 

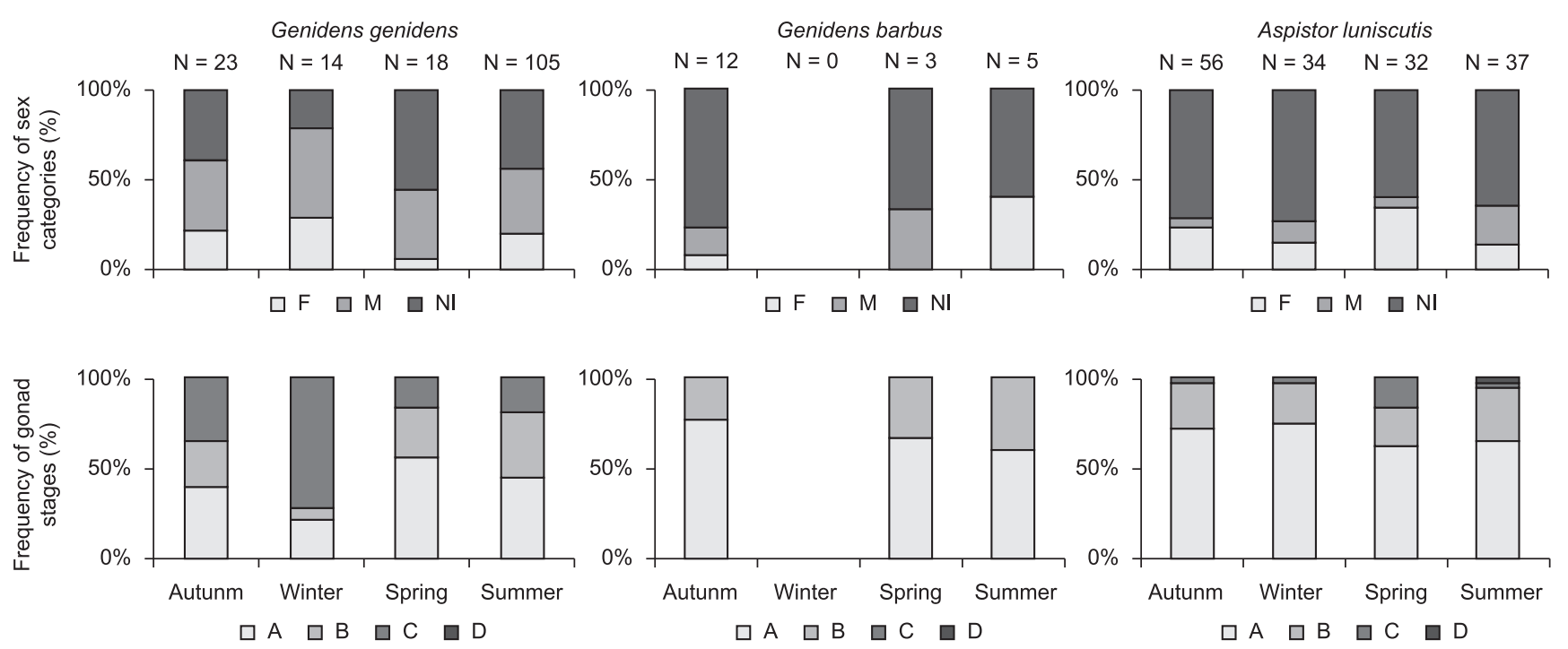

Figure 4. Genidens genidens, Genidens barbus, and Aspistor luniscutis. Frequency of the sexes (M=male; F= female; NI=not identified $)$ and gonad maturation stages $(\mathrm{A}=$ immature; $\mathrm{B}=$ in maturation; $\mathrm{C}=$ mature; $\mathrm{D}=$ post-spawning) by season.
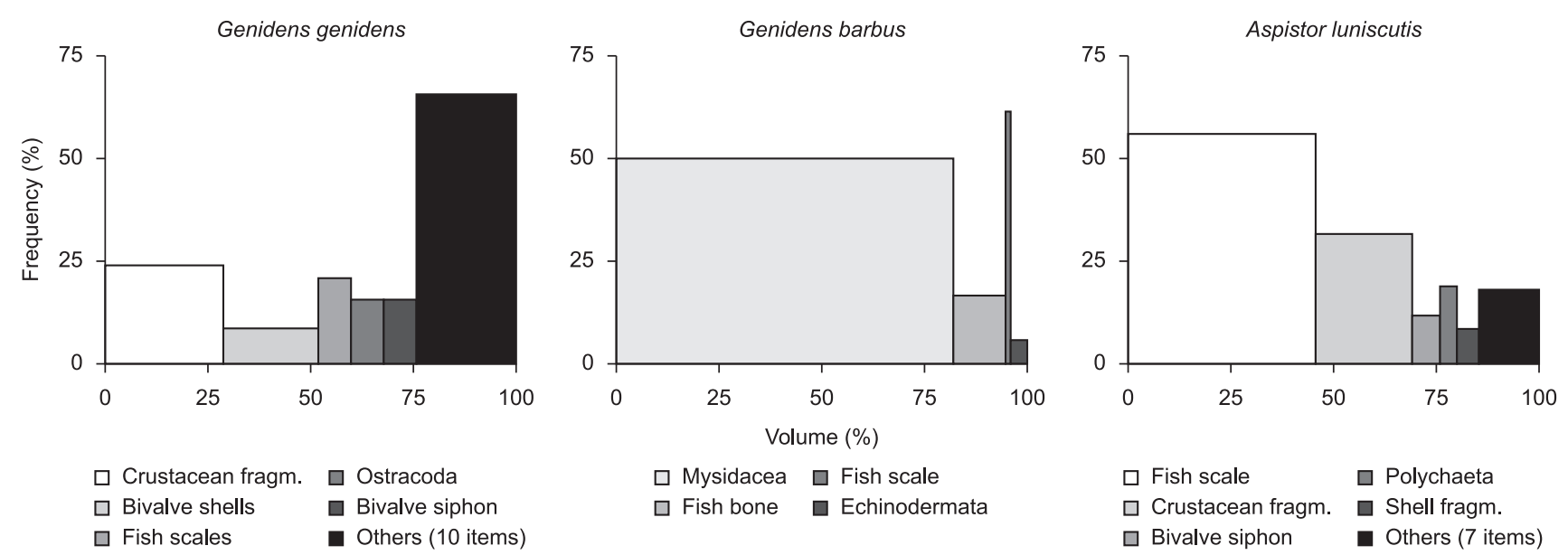

Figure 5. Genidens genidens, Genidens barbus, and Aspistor luniscutis. Relationship between the frequency of occurrence and the percent volume of the food items with higher importance in the stomach.

(1999) observed that $G$. genidens spawns during the summer and beginning of autumn in Sepetiba Bay (RJ) and concluded that the species is a K-strategist, evidenced by the protection given to the eggs and embryos and by their relatively large size. As assessed by Schmidt et al. (2008), the reproductive period of many catfish species is mainly related to the warmer months of the year or to the greatest input of continental fresh waters.

The DTL/SL ratio ranged between 1.15 and 1.43, suggesting that all three species may have omnivorous habits, since the digestive tube is longer than the standard length of the fish (Knöppel 1970). The higher importance of animal items in the diet may be due to an opportunistic habit, in which the fish eat the most available items. Of the three species, G. genidens showed the most diverse diet, with crustaceans, represented mainly by fragments, highly important. Other items with high relative importance were molluscs (shells), fish scales, ostracods, and bivalve siphons. The fact that crustacean fragments were the most voluminous item found in the stomach of this catfish seems to be more related to this fish's feeding habit than to the exoskeleton's resistance to digestion, which would result in overestimating the importance of this item, as discussed by Chaves
\& Vendel (1996). However, crustacean fragments were abundant in the stomach, and less so in the intestine. In contrast, mollusc shells were very highly important in the intestine and much less important in the stomach. These shells were found in the intestine even after the soft parts were completely digested, which did not occur with other items, and led to overestimation of molluscs.

Generally, studies on the diet of G. genidens report similar food items as in the individuals analyzed from Caraguatatuba Bay. Variations probably result from local particularities in the availability of the ingested items, in view of the general consensus among researchers that this is a generalist with opportunistic habits, strongly influenced by environmental conditions. According to Chaves \& Vendel (1996), the variations in the consumption of certain items may be associated with their availability, but also their exploitation by other predators. Mishima \& Tanji (1982) observed that, in the estuarine-lagoon complex of Cananéia, G. genidens fed mainly on decapods, molluscs and annelids. Araújo (1984) found that G. genidens, in the estuary of Lagoa dos Patos (RS), consumed Littoridina sp. (gastropod), Balanus improvisus (cirriped), Cyprideis multidentata (ostracod), and calanoid copepods. Chaves \& Vendel 

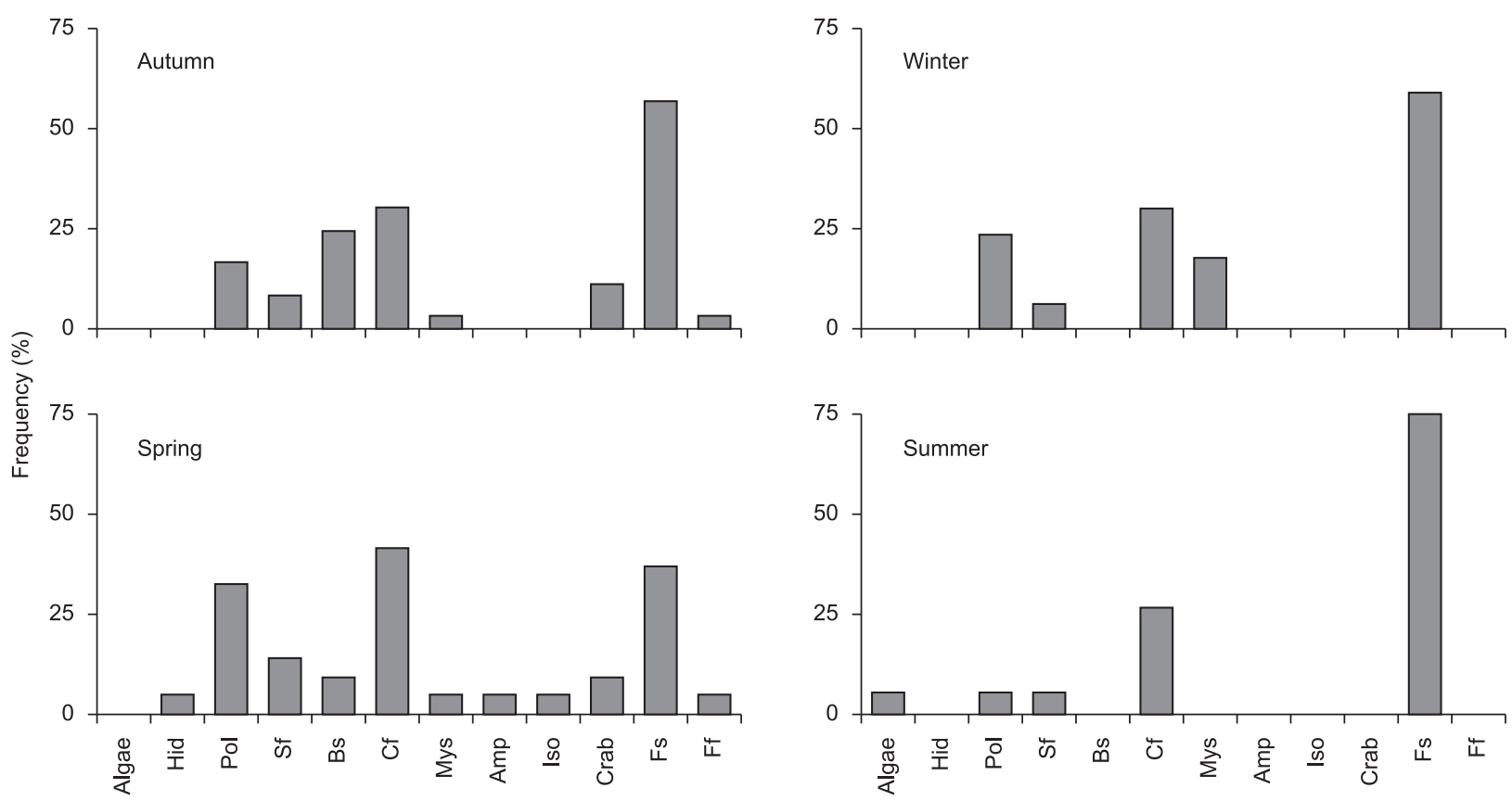

Figure 6. Aspistor luniscutis. Frequency of occurrence of the food items in the stomach, by season. $(\mathrm{Hid}=\mathrm{Hydrozoa} ; \mathrm{Pol}=\mathrm{Polychaeta} ; \mathrm{Sf}=\mathrm{shell}$ fragments; $\mathrm{Bs}=$ bivalve siphon; $\mathrm{Cf}=$ crustacean fragments; Mys = Mysidacea; Amp = Amphipoda; Iso = Isopoda; Fs = fish scales; $\mathrm{Ff}=$ fish fragments).

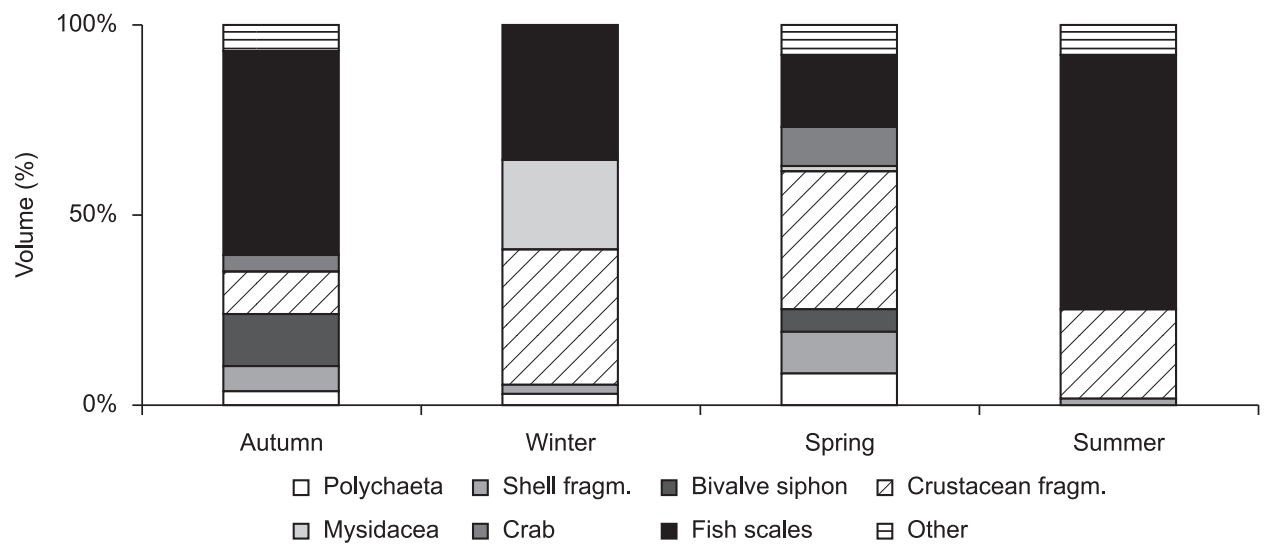

Figure 7. Aspistor luniscutis. Percent volume of the most voluminous food items in the stomach, by season.

(1996) observed that the diet of G. genidens in Baía de Guaratuba (Paraná) is mainly composed of decapods, followed by polychaetes. Rabitto \& Abilhôa (1999) noted that the items of greatest importance in the diet of G. genidens on a sandbank of Ilha do Mel (Paraná) were decapod crustaceans (41.72\%), unidentified material (42.32\%), and polychaetes (1.15\%). Pedra et al. (2006) obtained, in order of importance, the following items for G. genidens: crustaceans, fish, molluscs, and polychaetes.

Some studies refer to the importance of the strong tooth plates for G. genidens 'capacity to exploit rigid materials such as crustacean and mollusc shells and skeletons (Araújo 1984, Chaves \& Vendel 1996, Pedra et al. 2006). Chaves \& Vendel (1996) mentioned additional characteristics of the digestive tract that explain its generalist diet: dead-end stomach, which can store ingested items while digestion proceeds; large mouth opening, which allows prey to be ingested whole; and, to aid in recognizing items on the bottom.

The few individuals of $G$. barbus analyzed here showed a predominance of mysids in their diet. Large amounts of incompletely digested items were also found in the intestine, such as scales and amphipod tubes, probably resulting in an overestimate of the importance of these items. Mishima \& Tanji (1982) observed that G. barbus fed basically on decapods in the Cananéia lagoon-estuary complex. Reis (1982) found that the diet of adults of G. barbus in Lagoa dos Patos was composed of crustaceans of the families Caprellidae, Callianassidae and Callapidae, polychaetes of the family Magellonidae, and fish. Araújo (1984) recorded, in the diet of G. barbus, also in Lagoa dos Patos (RS), polychaetes, Mysidopsis tortonese (Mysidacea), and eggs of Micropogonias furnieri in the coastal areas and in the opening of the lagoon, and even soybeans (from the activities of the Rio Grande Port) and pereiopods of Callinectes spp. in the inner part of the lagoon.

Aspistor luniscutis based its diet on fish scales and crustacean fragments in Caraguatatuba Bay. Fragments of mollusc shells had high importance only in the intestine, indicating a possible overestimation of this recalcitrant item. Only Mishima \& Tanji (1982), in the lagoonestuary complex of Cananéia, referred to its diet, which was composed basically of decapods. 
Some studies of catfishes' diets refer to large amounts of detritus found in their digestive tubes (Araújo 1984, Chaves \& Vendel 1996, Rabitto \& Abilhôa 1999, Espírito Santo \& Isaac 1999). In Caraguatatuba Bay, practically all the digestive tubes of the three species contained large amounts of unidentifiable organic matter. According to Qasim (1972), the occurrence of detritus in large amounts is a peculiarity of estuarine fishes, and is abundant in their feeding. In addition, the catfishes possess a complex mouth apparatus, which allows them to crush the prey, often making it difficult to identify them.

An item that showed importance in the diet of the catfishes in Caraguatatuba Bay was fish scales. In fact, the consumption of fish scales has been documented for juveniles of the family Ariidae: Ariopsis felis (Hoese, 1966), Neoarius berneyi (Roberts, 1978) and Ariopsis seemanni (Szelistowski, 1989). Two hypotheses have been proposed for the consumption of scales: lepidophagy or saprophagy (ingestion of dead fish). Our findings of fish bones along with scales support the second hypothesis.

The diets of these three species of catfishes in Caraguatatuba Bay showed a slight overlap. Mishima \& Tanji (1982) associated differences in diet among the catfishes of the Cananéia lagoonestuary complex with the fact that Cathorops spixii, G. genidens and $A$. luniscutis live permanently in brackish waters, and show different feeding preferences and little variation in food composition in relation to their size; whereas migratory species such as G. barbus show ontogenetic differences in food composition. In Caraguatatuba Bay, the resource partitioning is better explained by the differences in the subhabitats occupied by the four species, as well as by the different proportions of the same item ingested. The differences in consumption of the most available items in the different seasons of the year, as observed for A. luniscutis in Caraguatatuba Bay, are probably another important factor that allows these catfish species to coexist.

\section{Acknowledgements}

This study was partially supported by the State of São Paulo Research Foundation (FAPESP) within the BIOTA/FAPESP - The Biodiversity Virtual Institute Program (www.biotasp.org.br). We thank Fapesp also for the "Programa Jovem Pesquisador em Centro Emergente" grant offered to M.R.D (Proc. Fapesp nos. 05/60041-6 and 06/57575-1). Project Aware Foundation supported parts of this research. Logistical support was provided by the Instituto Costa Brasilis - Desenvolvimento Sócio-Ambiental and also by the Centro Universitário da Fundação de Ensino Octávio Bastos. We thank Janet W. Reid by review of English grammar.

\section{References}

ALCÂNTARA, A.Y. 1989. Ecologia da ictiofauna do estuário do rio Sergipe (estado de Sergipe, Brasil). Tese de doutorado, Instituto de Biociências da Universidade de São Paulo, São Paulo.

ARAÚJO, F.G. 1984. Hábitos alimentares de três bagres marinhos (Ariidae) no estuário da lagoa dos Patos (RS), Brasil. Atlântica 7:47-63.

AZEVEDO, M.C.C., ARAÚJO, F.G., CRUZ-FILHO, A.G., GOMES, I.D. \& PESSANHA, A.L.M. 1999. Variação espacial e temporal de bagres marinhos (Siluriformes, Ariidae) na Baía de Sepetiba, Rio de Janeiro. Rev. Bras. Biol. 59(3):443-454. http://dx.doi.org/10.1590/S003471081999000300009

BARBIERI, L.R., SANTOS, R.P. \& ANDREATA, J.V. 1992. Reproductive biology of the marine catfish, Genidens genidens (Siluriformes, Ariidae), in the Jacarepaguá lagoon system, Rio de Janeiro, Brasil. Environ. Biol. Fish. 35:23-35. http://dx.doi.org/10.1007/BF00001154

BEMVENUTE, M.A. 1990. Hábitos alimentares de peixes-rei (Atherinidae) na região estuarina da Lagoa dos Patos. Atlântica 12:79-102.
BENTO, D.M. \& BEMVENUTI, M.A. 2008. Os peixes de água doce da pesca artesanal no sul da Lagoa dos Patos, RS - subsídios ao ensino escolar. Cad Ecol Aquática 3(2):33-41.

CHAVES, P.T.C. \& VENDEL, A.L. 1996. Aspectos da alimentação de Genidens genidens (Valenciennes) (Siluriformes: Ariidae) na Baía de Guaratuba, Paraná. Rev. Bras. Zool. 13(3):669-675. http://dx.doi. org/10.1590/S0101-81751996000300016

ESPÍRITO SANTO, R.V. \& ISAAC, V.J. 1999. Alimentação e aspectos da reprodução de uricica Cathorops spixii (Agassiz, 1829) (Osteichthyes, Siluriformes, Ariidae), no estuário do rio Caeté (município de BragançaPA). Bol. Mus. Para. Emílio Goeldi, sér. Zool. 15(1):95-111.

FÁVARO, L.F., FREHSE, F.A., OLIVEIRA, R.N. \& SCHWARZ-JÚNIOR, R. 2005. Reprodução do bagre amarelo, Cathorops spixii (Agassiz) (Siluriformes, Ariidae), da baía de Pinheiro, região estuarina do litoral do Paraná, Brasil. Rev. Bras. Zool. 22(4):1022-1029. http://dx.doi. org/10.1590/S0101-81752005000400030

FIGUEIREDO, J.L. \& MENEZES, N.A. 1978. Manual de peixes marinhos do sudeste do Brasil. V. Teleostei (1). Museu de Zoologia da Universidade de São Paulo, São Paulo, 110 p.

GOMES, I.D. \& ARAÚJO, F.G. 2004. Reproductive biology of marine catfishes (Siluriformes, Ariidae) in the Sepetiba bay, Brazil. Rev. Biol. Trop. 52(1):143-156.

GOMES, I.D., ARAÚJO, F.G., AZEVEDO, M.C.C. \& PESSANHA, A.L.M. 1999. Biologia reprodutiva dos bagres marinhos Genidens genidens (Valenciennes) e Cathorops spixii (Agassiz) (Siluriformes, Ariidae), na Baía de Sepetiba, Rio de Janeiro, Brasil. Rev. Bras. Zool. 16(2):171-180. http://dx.doi.org/10.1590/S0101-81751999000600017

HOESE, H.D. 1966. Ectoparasitism by juvenile sea catfish, Galeichthyes felis. Copeia 1966:880-881. http://dx.doi.org/10.2307/1441422

KAWAKAMI, E. \& VAZZOLER, G. 1980. Método gráfico e estimativa de índice alimentar aplicado no estudo de alimentação de peixes. Bolm. Inst. Oceanogr. 29:205-207. http://dx.doi.org/10.1590/S037355241980000200043

KNÖPPEL, H.A. 1970. Food of Central Amazonian fishes: contribution to the nutrient-ecology of Amazonian rain forest strems. Amazoniana 2:257-352

KREBS, C. J. 1989. Ecological Methodology. Harper Collins Publishers, New York, 654p.

MARCENIUK, A.P. \& MENEZES, N.A. 2007. Systematics of the family Ariidae (Ostariophysi, Siluriformes), with a redefinition of the genera. Zootaxa 1416:1-126.

MAZZONI, R., PETITO, J. \& MIRANDA, J.C. 2000. Reproductive biology of Genidens genidens, a catfish from the Maricá lagoon, RJ. Cienc. Cult. 52(2):121-126.

MISHIMA, M. \& TANJI, S. 1981. Distribuição geográfica dos bagres marinhos (Osteichthyes, Ariidae) no complexo estuarino lagunar de Cananéia $\left(25^{\circ} \mathrm{S}, 48^{\circ} \mathrm{W}\right)$. B. Inst. Pesca 8:157-172.

MISHIMA, M. \& TANJI, S. 1982. Nicho alimentar de bagres marinhos (Teleostei, Ariidae) no complexo estuarino lagunar de Cananéia $\left(25^{\circ} \mathrm{S}, 48^{\circ} \mathrm{W}\right)$. B. Inst. Pesca 9:131-140

PEDRA, M.L.R., OLIVEIRA, M.A. \& NOVELLI, R. 2006. Biologia alimentar do bagre Genidens genidens (Valenciennes, 1839) na Barra da Lagoa do Açu, norte do estado do Rio de Janeiro. Acta Biol. Leopol. 28(1):38-41.

QASIM, S.Z. 1972. The dynamics of food and feeding habits of some marine fishes. Indian. J. Fish. 19(1-12):11-28.

RABITTO, I.S. \& ABILHÔA, V.A. 1999. A alimentação do bagre Genidens genidens Valenciennes, 1839 em um banco areno-lodoso da Ilha do Mel, Paraná, Brasil. Arq. Ciên. Vet. Zool. Unipar 2(2):143-153.

REIS, E.G. 1982. Idade, crescimento e reprodução de Netuma barba (Siluriformes, Ariidae) no estuário da Lagoa Dos Patos (RS). Dissertação de mestrado, Universidade Federal do Rio Grande, Rio Grande do Sul.

REIS, E.G. 1986. Reproduction and feeding habitats of the marine catfish Netuma barba (Siluriformes, Ariidae) in the estuary of lagoa dos Patos, Brazil. Atlântica 8:35-55. 
RIBEIRO NETO, F.B. 1993. Análise ecomorfológica das comunidades de peixes do complexo baía-estuário de Santos e São Vicente. Tese de doutorado, Instituto Oceanográfico da Universidade de São Paulo, São Paulo.

ROBERTS, T.R. 1978. An ichthyological survey of the Fly River in Papua New Guinea with descriptions of the new species. Smiths. Contr. Zool. 281:172. http://dx.doi.org/10.5479/si.00810282.281

SANTOS, F.B., BESSA, E., TURRA, A. \& DENADAI, M.R. Unpublished data. Spatio-temporal structure of the demersal fish assemblage at the Caraguatatuba Bay, southeastern Brazil.
SCHMIDT, T.C.S., MARTINS, I.A., REIGADA, A.L.D. \& DIAS, J.F. 2008. Taxocenose de bagres marinhos (Siluriformes, Ariidae) da região estuarina de São Vicente, SP, Brasil. Biota Neotrop. 8(4):73-81. http:// dx.doi.org/10.1590/S1676-06032008000400006

SZELISTOWSKI, W.A. 1989. Scale-feeding in juvenile marine catfishes (Pisces: Ariidae). Copeia 2:517-519. http://dx.doi.org/10.2307/1445459

UIEDA, V.S. \& CASTRO, R.M.C. 1999. Coleta e fixação de peixes de riachos. In Ecologia de Peixes de Riachos (E.P. Caramaschi, R. Mazzoni \& P.R. Peres, eds.). Sér. Oec. Bras., v.6, p.01-22.

VAZZOLER, A.E.A.M. 1996. Biologia da Reprodução de Teleósteos: Teoria e Prática. Eduem, Maringá, 169p. 